\title{
Wittgenstein and Literature
}

Brian McGuinness, Siena

There are obvious ways in which the study of Wittgenstein's thought must have recourse to the facts of his life. The innocent reader, der Unbefangene, who reads "The world is all that is the case" or the description of St. Augustine's account of a child's learning (or rather coming) to talk may be swept along by the author's art like someone caught up in a conversation on a Russian train, and this is in part the aim. But when reflection sets in he is bound to ask who the author is and what cultural assumptions he is making. There are literary and other allusions that the reader needs to catch and this cannot be done without some knowledge of the background and even education of the author. This becomes more necessary as these, from being alien in language and geography, become also remote in time. There are further difficulties arising from the fact that Wittgenstein's "works" are for far the most part the product of posthumous selection and editing, in the first place by trusted friends and then by those whom these in turn trusted. Such works are incomplete if left without some account of their genesis and genre - for the author is not there to define them. Such an account will necessarily explain what Wittgenstein was engaged on at various times of his life and any hindrances that prevented him for all second half of his life from producing a finished work - die wohlgeratne Butterwälze, the well turned out slab of butter, to which Wilhelm Busch, deliberately down to earth, likens the final product of the poet.

But apart from the facts that "a shilling life will give you", what help to the understanding of his philosophy does the detail, whether core or husk, of his life give us, fascinating though that it may be in itself? Isn't biography in the end a distraction from our aim of understanding his thought? Do we need to know "what porridge had John Keats"? When Paul Engelmann was planning the publication of the first memoir describing Wittgenstein's early life, Elizabeth Anscombe told him that if by pressing a button she could have destroyed all biographical material, she would have 
done so. Margaret Stonborough (Wittgenstein's sister) told Hayek, who had similar plans, that Ludwig would have disdainfully rejected any idea of a "life" that went into his education, family, and feelings. We owe to the dead respectful silence: his work would speak for him.

Yet Wittgenstein himself could almost be said to have lived his life in order to recount it (to borrow Garcia Marquez's title Vivir para contarla). After a life, full of change and incident, certainly, but one would have thought sad, he said it had been a wonderful one. We shall see later why it was only at this moment that it could be seen as such. From all the accidents there had been something to learnt or won. Everything was lived at a high level of interiorization. Every element: war, love, rejection, the death of loved ones, exile, racial persecution, concern for his sins and salvation was wrestled with in search of the perfect - usually the most difficult - solution and this was usually a search for the right spontaneous reaction (a typical Wittgensteinian paradox or "double bind"). And this wrestling was not so much recorded as conducted in diaries or Tagebücher. Reading of books so entitled - by Tolstoy, Kierkegaard, Dostoevsky and Gottfried Keller - was part of the culture of his generation of the family. They tended to model and guide their lives by literature such as this. It was perhaps their nearest approach to religion. Much of the most intimate part of Wittgenstein's own diaries was written in a simple code understood in his family, as if it were addressed to them, like one of the "confessions" (Geständnisse) he often talked about and more than once made. The most confessional volume of his diary passed after his death to his most trusted sister until she confided it to his best friend in Austria. Only recently has it come to light.

In Keller we find the idea that keeping a diary was the only road to integrity and constancy: a man should always be reflecting on his own character. (We are not far from Socrates' ho anexetastos bios ou biôtos anthrôpôi.) Wittgenstein in general had more need of it than Keller. There were intervals - in a note of 1929 (just returned to Cambridge and philosophy) he comments that (strangely enough, as he significantly says) he had for some years not felt this need and indeed we have no Tagebücher between the wartime notebooks and precisely this remark. The only writings that remain from that period are reports of dreams (W. W. Bartley III must have seen some of these) and a brief sketch of an autobiography covering 
his earlier years. Since these were preserved it is unlikely that much else was destroyed. He was trying to collect his thoughts, as he told Keynes, and clearly some of these ran towards "biography" (autobiography was meant) but he did not get far. In these years he tried everything but philosophy to occupy himself - architecture, music, physical labour, sculpture. It is natural to think that he, like the comrades from whom he received letters, was recovering from the war, which marked so many of his generation. F. R. Leavis noted this as late as 1930 . It is a natural speculation that his reluctance to return to philosophy was a part of this crisis. He gave it up, just as he gave away his fortune.

What is interesting is that it was when he returned to philosophy that the writing of diary-like notes again seemed natural. In the notebooks in which he recorded his thoughts for future reflection or use, personal reflections abound. He interrupts his philosophical writing to exclaim, sometimes but not always in code, on his weaknesses, his vanity, his sins or his aspirations -all of which of course might infect his philosophical writing as much as any other aspect of his life. He constantly felt that he could easily relapse into vanity, in philosophy as elsewhere. In the case of autobiography itself (he said, reflecting on his current activity) this would compound his faults, make him yet schmutziger (sully him yet further). One mustn't minimize, embellish, or pretend but, like Pepys (whom he added to the list of models), write at the level of the life one lived, neither exploring what lay beneath the surface ${ }^{1}$ nor looking down from a height. One may say that his real life was there in such writing. He once wrote:

Something in me speaks in favour of writing my biography. The fact is I want for once to spread my life out clearly, so as to have it clear in front of me and also for others. ${ }^{2}$

His first aim was, as he often said, mit sich selbst ins reine zu kommen, to come to terms with himself, to see and accept, and by so doing change, as

${ }^{1}$ To be sure, he (like Keller) included dream reports, but these are treated (almost biblically) as moral insights.

${ }^{2}$ MS 108, 47 (28.12.1929): "Etwas in mir spricht dafür meine Biographie zu schreiben und zwar möchte ich mein Leben einmal klar ausbreiten um es klar vor mir zu haben und auch für andere." 
far as was possible, his nature - as a poor sinner, as he was wont to say I a Dostoievskian way - and with Dostoyevskian pride.

The particular form of his own life Wittgenstein saw as a function of his unhappy family, from which each member tried to escape in his own way $^{3}$. He said this in a letter to his then only surviving brother and it is natural to suppose that he is thinking particularly of the sons, of whom three had already committed suicide. There were failings too on the female side: he speaks later of making a confession on behalf of his mother, which her withdrawn nature would not have allowed her to make for herself. Perhaps her withdrawn character was what she had to confess. He found her love stifling and indeed thought that the whole female family erred by excess of Liebenswürdigkeit. This is of a piece with his fiercely holding himself aloof from his sister Hermine in the 1920s. His relation with the active sister, Margaret, was the nearest to a relation of equals, but note that she defined herself by, wanted to be known for, the achievements of her father, brothers and sons. The male element was the defining one, typified by the father, the great industrialist who carried all before him. Wittgenstein hardly ever speaks of his attitude towards his father (who died when he himself was 24): in notes for a biography (mentioned above) ${ }^{4}$ he juxtaposes "Latin exercises for Papa" with "Thoughts of suicide" and we know that his father (not the most patient of men) became dissatisfied with the poor results of home education. At the end Wittgenstein wrote movingly to Russell of his father's "most beautiful death. ... I think that this death was worth a whole life", Perhaps through all his life the philosopher was hoping for such a death himself, the totum simul (the unique chance to see one's life as whole), the acceptance ${ }^{6}$. The figure of his father perhaps also appears in the constant struggle within him between male and female elements (Weininger's classification actually fitted this family situation). A

${ }^{3}$ Letter to Paul Wittgenstein. All letters quoted can be found in the Gesamtbriefwechsel published online (and on CD-ROM) by InteLex. On the theme of the family see: McGuinness 2006.

${ }^{4}$ See McGuinness 2001, p.48.

5 "Letter to Russell, 22.1.1913", in: McGuinness 2008.

${ }^{6}$ He repeatedly recommended to friends Tolstoy's The Death of Ivan Illich, where the dying man is finally redeemed by his acceptance of what is happening. 
degree of violence and intolerance was expected of the brothers, following the model of the father ${ }^{7}$. Commenting on how difficult it was to share a house with Paul, one sister says, "But suppose it had been Kurt!" The Wittgenstein we are concerned with was after all the easiest of these three. He indeed favoured in theory the driven and practical side of his father, so he started life as an engineering student with the design of being an aviator, and later he wanted to do philosophy in a businesslike way. Two of his brothers tried to escape from the father's model through music: one seems to have been driven to suicide, the other (Paul) succeeded in living a musician's life, but (since he had to overcome the loss of his right arm) only by supreme efforts of will. Ludwig, for his part, said that music was half of his life, but a half he had written nothing about: compare his remark that his mother had never brought a thought to completion except at the piano. In this and many ways the female side of him was obvious to others - his sisters thought of him as the Alyosha of the family, and he was probably thinking of this identification when he exclaimed, "I am Smerdyakov, I am Dr Mabuse!"

He made a rather different (but not contradictory) exclamation to Moore, "Of course I want to be perfect", but deep rifts within him made this bewildering for others - perhaps an inevitable consequence of the overweening ambition it represented ${ }^{9}$. He could be the kindest and most inspiring of friends and companions. But his very force of character meant that his fierceness when it broke out issued in breaks with friends and denunciations. He could be a charming companion when met by chance but also, when he had not established a relationship, be timid, tongue-tied and awkward. He accused himself of cowardice, though his almost foolhardy courage in the First World War is well attested. It is impossible not to be

${ }^{7}$ Hermine describes Paul's left-handed playing as a "Vergewaltigung" (here not quite "rape"): as if he were doing violence to the music, the piano, or himself. She also says it reminds her of something in their father.

${ }^{8}$ It is relevant that Alyosha in fact understands and shares the impulses of the others: he too is a Karamazov.

${ }^{9}$ Moore incidentally was quite unaware of his own inability to compromise, his own perfectionism, see below. Averse as he was to religion he either did not catch or deliberately ignored the echo of the Gospel precept "Be perfect therefore as your heavenly Father is perfect", Matthew 5.48. 
reminded of Freud's well-known analysis of Dostoevsky ${ }^{10}$ : a man of the greatest need and capacity for love possessed by destructive tendencies directed chiefly (but not only) against himself, full of feelings of guilt, writing about great sinners and presenting himself as one of them, given to attacks of illness, constantly speculating on the possibility of an early death, his greatest wish to die in an inspired moment, such as often preceded his epileptic attacks. Freud saw here a need to be punished, stemming from Dostoevsky's relation with his father and thought that the neurosis so generated finally led to a misapplication of great affective and intellectual gifts. Still Freud himself thinks The Brothers Karamazov one of the four great (of course Oedipal) works of Western civilization and the neurosis was perhaps necessary for its production. If analysis had counterfactually changed Dostoevsky into a progressive liberal, he could never have written that book.

A Freudian account of his own life would have had little interest for Wittgenstein either. The only advantage he saw in a nephew's entering analysis was the shame bound to be engendered by all the things he had to admit to his analyst. Confession was of the first importance. When Wittgenstein said, in 1931, that it (eine Beichte) must be part of the new life (scil. that he meant to lead), he was not saying that confession without a new life was pointless but that no change was possible without confession. A true life meant the acknowledgement of all the meanness of the past and not just, as in Goethe's ideal vision, confession to a wise adviser who will enable one to bear the burden of guilt and order one's life better ${ }^{11}$, but precisely to those on whom or in relation to whom past meanness or deceptions have been practised. Thus in 1931 and again in 1936-7 he went round (or when necessary wrote) forcing on former pupils now peasants or on relations, friends, colleagues or patrons, recitations and requests for forgiveness that they often misunderstood and whose purpose baffled them, "eccentric" Keynes called it, and we have seen Moore's reaction. Others

\footnotetext{
${ }^{10}$ Freud 1929. Even those who point to Freud's limited biographical knowledge and a certain lack of scruple in enhancing it admit the value of his insights. See e.g Joseph Frank: "Freud's article contains some shrewd and penetrating remarks about Dostoevsky's masochistic and guilt-ridden personality" (Frank 1977, 28).

${ }^{11}$ In Dichtung und Wahrheit.
} 
wrote saying that they thought even better of him, so George Thomson and Ludwig Hänsel. "What a tripwire!" Wittgenstein exclaimed, though his mentor Wilhelm Busch could have told him what would happen ${ }^{12}$. His aim had been to destroy a whole edifice of lies (as he thought it) that made him seem better than he really was. By (again) a Wittgensteinian double bind the effect was, not to establish the truth, but to make him seem better or worse than was the reality. Part of what he had hoped, to judge by a later passage, was that persons who both loved and valued him would make this humbling of himself easier for him.

For the confessions were not something owed to them but were principally parts of his effort to reach a true life for himself, precisely by recognizing (not just writing) that he was an armer Sünder, a miserable sinner. This is what Spinoza had failed to do, so that his remarks about himself left Wittgenstein uneasy ${ }^{13}$. The admission of guilt (Geständnis is the word he uses in these passages) is the recognition of one's own worthlessness. Unable to be good, he muses (tentative as always in religious matters), this recognition of worthlessness may enable a man to have faith in and identify with a Redeemer who will take the guilt from him.

But how did his philosophy enter into this and do we need to know this life or "Life" in order to understand or profit from that philosophy? At some times he thought his work was comparatively unimportant. It dealt with one form of the illusions of grandeur or profundity that beset us - but only some of us, the thinkers. Its methods though are the same in essence as those required in the moral sphere. A man has to realize that he is just a man ("Er ist, wie die Menschen sind." was a typically dismissive judgement.) and to be aware of the temptations and idols that mislead him. Again and again in philosophy it is a problem of the will not of the understanding that is attacked. This accounts for the passion that sometimes invested Wittgenstein's criticism of the mathematicians for example. We may compare G.E.Moore's, though a kindly man, going red at the neck in discussion. For these two, philosophy was not a game. Truth had to be sought seriously. But that brings us near to another temptation: vanity and the wish to win at all costs. (There was vanity too in the composition of the

\footnotetext{
12 Paul Engelmann copied out as a warning to himself Busch's "Die Selbstkritik".

${ }^{13}$ In a confessional notebook from Norway (MS 183, 96) 12 October 1931.
} 
Tagebücher and the invention of similes - another Wittgensteinian "bind".) I think it is arguable, however, that his method in philosophy was Wittgenstein's nearest approach to the insight he wanted to convey generally, a help to see the world aright. Wittgenstein's own example was that of the "hero" at the end of Wilhelm Busch's Eduards Traum. Only a man of heart can see that he is worth nothing and then everything will turn out right. Das Weitere findet sich, says Wittgenstein too at the end of one of his most fervent Bekenntnisse and perhaps this was the kind of tranquillity he hoped his philosophy would lead to (He frequently quoted Heinrich Hertz's ideal: der nicht mehr gequälte Geist.)

Nicht mehr gequält zu sein, "not to be tortured any more" - the ideal reminds one of Dean Swift's epitaph ubi saeva indignatio ulterius lacerare non posset, "where (i.e. in the grave) fierce indignation can no longer tear his heart". The solution in philosophy is to be at peace with oneself, that of life is nothing other than death. A complete catharsis indeed. We shall see shortly what Wittgenstein thought of tragedy in an exchange of letters with his brother Paul (the one-armed pianist) at the beginning of 1935. Be it said here that there is something tragic about all Wittgenstein's writings - a clash if not of modes of life, of ways of seeing or talking about them. None of them do we want to abandon and yet we feel the tension. Hence the polyphony of his works which has been noted - and compared with Dostoevsky ${ }^{14}$.

To return to the correspondence with Paul. The relation between the two brothers had, it seems to me, spontaneity, without a shadow of dutifulness or formality. How much this had to do with maleness, how much with the fact that they had been close in age, joint Benjamins of the family when it went through a number of crises, how much to intellectual affinity I must leave to emerge.

Paul was the elder by two years and always the more practical and worldly wise. He would tell Ludwig how to deal with the High Command

\footnotetext{
14 The tragic character of Dostoevsky's novels and the polyphony this gave rise to were first noted by Vyatcheslav Ivanov, though the latter feature is now frequently associated with Mikhail Bakhtin. It is quite uncertain whether Wittgenstein knew the work of either, though Mikhail's brother Nicholas Bachtin was a close friend of his at one time.
} 
when the latter wanted to change his arm from artillery to infantry during the war: later he would explain how impossible it was for Ludwig, even in a mountain village of Lower Austria, to conceal his membership of their well known family, just as he had told him when they were children that it was impossible to conceal their Jewish descent in order to get into a gymnastic club. All this without any condescension, as between brothers. Ludwig perhaps took the lead when it was a matter of personal relations within the family, explaining very rationally to Paul why he should not take offence at what seemed to him a reluctant invitation to perform for the others $^{15}$. But otherwise there was an exchange between equals. Ludwig would send Paul friends or old comrades for practical help, just as Paul would ask Ludwig for information on comrades when he needed it. Paul showed especial kindness to Ludwig's friend and younger colleague $\mathrm{Ru}-$ dolf Koder, offering piano lessons and introducing him to the world in other ways. He even bought him a dinner jacket.

When, after his teacher training in Vienna, Ludwig went to live in the first of his villages, Paul provided support in an unobtrusive way, packages of food and the like. Paul seems to have been fairly sure of being welcome - he offers to come over and play a particular piece of music whereas their sister Hermine had great difficulty in obtaining an invitation. Paul sometimes walked across from the Hochreith ${ }^{16}$ with a book in his pocket, which he meant to read to Ludwig. A letter one March mentions such an intention, though the road was not yet open. The book on that occasion was Daudet, though for himself Paul usually carried Vergil. During a later eremitical period in Ludwig's life Paul would send blankets, dried pea soup, chocolate - whatever was required - to Norway. Ludwig protested, but mildly, at this practical charity, which came wrapped in goodnatured humour ${ }^{17}$.

${ }^{15}$ For another example of Ludwig's peace making within the family see: Prokop 2003, p.199.

${ }^{16}$ A serious walk, but one fitting into the almost fanatical regime by which he was able to overcome the loss of his right arm.

${ }^{17}$ Herzlichen Dank für die „Südfrüchte“! Schokolade, Wurst \& Käse sind aber keine Südfrüchte und überhaupt solltest Du Dich ein bißchen mäßigen! wrote Ludwig (Thank you for the "tropical fruit" - but chocolate, sausage and cheese are not tropical fruits and anyway you should be more moderate!) Paul jokingly said that 
Literature was one bond for these two. Paul loved to quote the German classics: it is an indication of common tastes that, to soften some advice to Ludwig, he said, "It is physic not poison that I offer you ${ }^{18, ", ~ a ~}$ quotation from Nathan der Weise - just when (though he can hardly have known this) when Ludwig was reading the same play. (We find it as a point of reference again in these letters. It was part of what I have called their geistige Kinderstube or intellectual nursery training.) That Paul read to Ludwig we know only from the letter quoted above, but it is of a piece with Ludwig's reading Johann Peter Hebel to the young people in the Renngasse $^{19}$ and Wilhelm Busch or Rabindranath Tagore to the bemused philosophers of the Vienna Circle ${ }^{20}$. The brothers shared their reading as they shared their music, all in the family manner. These new letters indicate the sort of conversations that the two will have had. Paul (who has been unable to see Ludwig at Christmas) criticizes Friedrich Hebbel's Nibelungen, comparing it unfavourably with Wagner's treatment of the same material, on account of its mixture of ancient and modern, pagan and Christian elements and of other infelicities ${ }^{21}$.

Ludwig answers on 26.1.1935 with great appreciation of Hebbel. Perhaps indeed (Joachim Schulte has suggested) Paul is being provocative here, siding with later taste against one of the family's household gods. For Hebbel had been an associate of their grandfather Hermann Christian, along with Ernst von Brücke (a relation by marriage), Bonitz and other members of the German and evangelische Colony in Vienna ${ }^{22}$. Ludwig's reasoning is in part wrong-headed and unfair to Wagner - think of the Meistersinger! - but in general perceptive and provocative and couched in

"as well-fed as a board school teacher in a mountain village" had become proverbial. In fact, times in Austria were very hard after the war.

18 "Es ist Arznei nicht Gift, was ich Dir reiche".

${ }^{19}$ Marguerite Sjögren (previously Respinger) in Granny et son temps A la Baconnière, 1982, p.100, writes of hearing "la poésie de mon pays alémanique lue avec une compréhension profonde" - Galeotto fu il libro e chi lo scrisse, we might say, for this was the beginning of an intense and tortured relationship. ("The book and its author were pandars to us", the words are those of Dante's Francesca.)

20 See McGuinness 2002.

${ }^{21}$ See Appendix (or Handout) for the relevant part of the text.

${ }^{22}$ So Hermine Wittgenstein in her Family Memoir. 
the style that was brought out in Ludwig by conversations with valued friends - Sraffa or Engelmann, for instance. In his family it was his brother that could best elicit it. Paul had what Ludwig needed in an interlocutor, a brisk intelligence and a slashing style, the latter surprisingly akin to Paul's impetuous German cursive hand, a hand, by the way, such as none of his carefully westernized brothers and sisters used. His literary style (so to term it) recalls that of his father, whose essays on economic matters and practical politics show equal contempt for the amateur and the professor ${ }^{23}$.

Another bond between them was music, which was all of Paul's life and half (so he himself said) of Ludwig's. It dominated family life and hospitality in the Alleegasse and (it seems) would bring Ludwig back when little else could. Paul writes often to ask what he should prepare to play fourhanded - for Ludwig when he came - their mother and Fräulein Staake are mentioned as his accompanists. Brahms's Haydn variations, Weber overtures, Bach trios and works by Josef Labor are examples of what was prepared. On a special occasion the violinist Fräulein Baumayer would play and Helene sing, just for Ludwig. These were not meant to be concerts, but concerts were also organized - usually for the music of Labor, their "house composer". This term is not an exaggeration in the "Wittgenstein" literature ${ }^{24}$. Nearly all Labor's compositions after 1915 were commissioned by Paul and the composer's frequent use of the clarinet surely either influenced or was influenced by Ludwig's choice of that instrument for both relaxation and schoolwork ${ }^{25}$. The taste for Labor corresponds to Ludwig's remark that his own cultural ideal was not one of his own time (ein zeitgemäßes) but perhaps of the time of Schumann, or at least $a$ continuation of the ideal of that period though not the one that actually occurred $^{26}$. Here he perhaps overlooks (as Joachim Schulte points out) Brahms and Bruckner, whom he did admire - on the other hand Labor (whom Ludwig also admired) with his gentle eclecticism was an exception in his own period and so a confirmation of the remark. Paul's agreement in

\footnotetext{
${ }^{23}$ See Wittgenstein 1984.

${ }^{24}$ See Alber 2000.

${ }^{25}$ Certificates, however, show that Ludwig offered the violin as his instrument at the Teacher Training College.

${ }^{26}$ Culture and Value p. 2.
} 
taste should be noted: whatever about his performance style, he too was a musician of the nineteenth century (as Prokofiev sensed ${ }^{27}$ ).

Paul's playing was not always appreciated in his family. "Muß man so dreschen! " ("Does he have to pound the piano like that!"?) his mother is reported to have said and in a letter from New York Margaret, after hearing one of his recitals, incognito in consequence of a rift in the family, writes "his playing has become much worse. I suppose that is to be expected, because he insists on trying to do, what really cannot be done. It is eine Vergewaltigung" (Letter of 1942). Ludwig has deeper reasons for criticism (and at a period when Paul's playing was still at its best). In a letter of the 1920's (no nearer date is known), he writes to Paul:

I think you are unwilling to lose yourself in and behind the composition: on the contrary, it's yourself that you want to present. I am well aware that, that way too, something comes out that's worth hearing, and I don't mean just for a hearer who admires the technique, but also for me and for anyone who can appreciate the expression of a personality. On the other hand I wouldn't turn to you if I wanted (as I usually do) to hear a composer speak.

But even here there are a couple of exceptions, I mean, for example Wagner. (I won't now start to philosophize about why you bring a different sense to your interpretation of Wagner from that of most other composers.) And also Labor, whom you play with a certain self-renunciation (or so it seems to me). ${ }^{28}$

Wagner's total conception of the world corresponded to something in Paul's character, who had more of the masculine violence of his father he was the Dmitry among the brothers, if one may yield to the parallel with Karamazovs that almost imposes itself, while Ludwig (often in his lifetime thought of as an Alyosha) might better be seen as the Ivan. In Paul's case this was of a piece with his adherence to the school of Leschetitzky and virtuoso music, while Ludwig was more at home with the Hausmusik of the earlier period. Ludwig too had in him more of the feminine side of the family, as he sometimes admits. He thought himself lazy like his brother Kurt (who however was more violent in the family circle). In various as-

\footnotetext{
${ }^{27}$ In a letter, where he points out that his own is, of course, music of the twentieth century, quoted in Flannel 1971, 120.

${ }^{28}$ See Appendix.
} 
pects of his life it is clear that he had great difficulty in reconciling divergent elements in his personality (elements akin to the $\mathrm{M}$ and $\mathrm{W}$ of Weininger). For this reason he always thought and usually wrote dialectically. Both sides of each philosophical question had to be heard, a decisive solution was hardly attainable. More important still was the difficulty of reconciling himself with the person that he was and of being true to personal relationships or to his aspirations in life. The only guide was what - in the situation of the moment - was acceptable, tolerable, what one could live with, what one could face the world (or a friend or one's Maker) with, what one didn't feel to be in bad taste (all of these are attempts to translate anständig or related words). Thus his own behaviour might seem impulsive rather than principled, for the principle was at a higher level. These moral attitudes are mirrored (for him it was inevitable) in the artistic preferences such as we find here. He could not, in serious art, expect a resolution, a Happy End. Wagner has been thought of as a Schopenhauer without the pessimism, because he sometimes glimpses, sometimes proclaims such a resolution, but Ludwig preferred the starker recognition of incompatibles. They are what set the tasks of life for us. Whoever failed to face these had gone to the dogs - the Devil had indeed taken him - to echo a frequent invocation of his. He preferred or understood the final despair of Lenau's Faust (kin to Marlowe's) rather than the transfiguration envisaged by Goethe. In a remark some have found surprising he said at the end of the War, "What a terrible position a man like Hitler is in at the moment." Ludwig (like the Dostoevsky he so much admired) could envisage only too vividly the extremes of sin and guilt. Only on his deathbed did he totally succeed in feeling or seeing that he had escaped them.

It is a saddening index of the time in which these letters were written that Ludwig takes the basic problem faced in the works discussed to be that of race, implicitly echoing Paul's scorn for what he thought the gratuitous introduction of Christianity at the end of the Nibelungen. Yet Hebbel's trilogy turns at every point on how near, or how fully committed to the new religion the figures depicted are. Hebbel is attempting to describe the victory of Christianity over paganism, evidently not a victory without human cost. True he thought religion a mythology among other mythologies, but still it was a powerful one. This theme is not absent from Wagner either. A largely racial treatment of these myths, on the other hand, was de- 
tected if not intended in the Fritz Lang's 1920's films of the Nibelungen (loosely based on Hebbel or on the original, not on Wagner's re-working), which became cult-films for the Nazis by the date of our letters. Fritz Lang, himself half-Jewish (as one was forced to say) but surely not for that reason had drawn his wicked figure from a particularly vivid presentation by the visiting Habimah, thus enabling Goebbels to say with typical cynicism, "The Jews have provided us with the weapons to use against them." An example, in more ways than one, of how everything can be distorted.

\section{Literature}

Alber, Martin 2000: "Josef Labor und die Musik in der Wittgenstein-Familie”. In: Alber, Martin / McGuinness, Brian / Seekircher, Monika (eds.): Wittgenstein und die Musik. Innsbruck: Haymon-Verlag.

Flannel, E. Fred 1971: "Paul Wittgenstein (1887-1961): Patron and Pianist". Musical Review 32.

Frank, Joseph 1977: Dostoevsky: The Seeds of Revolt.

Freud, Sigmund 1929: "Dostojewski und die Vatertötung". In: Gesammelte Werke, 14, 397-418. "Dostoevsky and Parricide". In: Wellek, René 1962: Dostoevsky: A Collection of Critical Essays. Englewood Cliffs, N.J.: Prentice-Hall, 98-111.

McGuinness, Brian 2001: Young Ludwig, Oxford.

McGuinness, Brian 2002: Approaches to Wittgenstein. Oxford: Routledge.

McGuinness, Brian 2006: “The Brothers Wittgenstein”. In Suchy, Irene / Janik, Allan / Predota, Georg (eds.) 2006: Empty Sleeve, Der Musiker und Mäzen Paul Wittgenstein. Innsbruck: Studienverlag, 53-66.

McGuiness, Brian (ed.) 2008: Wittgenstein in Cambridge. Oxford: Wiley-Blackwell.

Prokop Ursula 2003: Margaret Stonborough Wittgenstein. Vienna: Böhlau.

Wittgenstein, Karl 1984: Politico-Economic Writings, ed. J. C. Nyíri, John Benjamins. Amsterdam / Philadelphia. 


\section{Appendix: Letters exchanged between Paul and Ludwig ${ }^{29}$}

Paul to Ludwig. 12.1934

The first disappointment was Hebbel's Nibelungen [a trilogy]. I find them a total failure. This starts even in the dedication - to his wife "So take this depiction, into which you have breathed life, for yours it is, and if it has power to endure, then let the fame be entirely yours" [Hebbel's wife's acting of Brunhilde in another dramatist's work had indeed given Hebbel the courage to attempt a dramatic treatment himself]. A dramatist who writes a dramatic trilogy should have some higher aim! Then there's this mixture of antique and modern themes - a mistake Wagner doesn't make. When Siegfried goes on his travels, Kriemhild is told to pack the armour on top! We hear "that old folk are so attached to animals" and yet at the same time we have the pre-historic fairytale figure of Brunhilde from Isenland.

Hagen and Gunter, who behave in a craven and mean fashion in Parts 1 and 2, become heroes in the last section. (Even if that's how it is in the [original] epic, that's no excuse for a dramatist.)

Why on earth has Kriemhilde's Revenge 5 Acts? The plot is stretched out like dough for strudel. If she wants to slay Hagen why doesn't she do it at once?

The whole time she talks of wanting to avenge Siegfried, but in the last scene when she does slay Hagen, she suddenly begins with the treasure of the Nibelungs, which has only been casually mentioned before. So she was only concerned about the gold?

At the end Dietrich von Bern takes over the rulership "in the name of Him who expired on the Cross". So here we have another new theme, which has at most been hinted at before. There's no rhyme or reason in all this.

Not to mention the fact that Brunhilde after having been introduced so solemnly is simply lost sight of! (Here too Wagner is more logical.)

No doubt these mistakes are outweighed by merits that I fail to recognize, but mistakes they remain.

Die erste Enttäuschung waren die Hebbelschen Nibelungen: ich finde sie ganz verfehlt. Anfangen tut's schon mit der Widmung an seine Frau... "drum nimm es hin, das Bild, das du beseelt, denn Dir gehörts, \& wenn es dauern kann, so sei's allein zu deinem Ruhm..." Wenn ein Dichter eine Dramen-Trilogie schreibt, muss er Höheres bezwecken.

${ }^{29}$ Material quoted from Ludwig and Paul Wittgenstein by kind permission of the Master and Fellows of Trinity College, Cambridge, and the Heirs of Paul Wittgenstein respectively. Translations by Brian McGuinness. 
Dann diese Mischung von Antike \& Neuzeit (ein Fehler, den Wagner nicht macht): Kriemhild soll, wenn Siegfried auf die Reise geht, den Panzer zu oberst einpacken!!! Siegfr. Tod, 4. Akt 6. Szene. Kriemhild: ... "dass alte Leute, so an Thieren hängen" (Kriemh. Rache, 1. Akt. 3. Szene). Aber daneben die ganz vorgeschichtliche märchenhafte Brünhilde aus Isenland.

Hagen \& Günther, die sich im 1.\& 2. Theil gemein \& niedrig benehmen, werden im letzten Stück zu Helden. (Sollte das im Epos auch der Fall sein, so ist das keine Entschuldigung für den Dramatiker)

Warum hat überhaupt Kriemhilds Rache 5 Akte? Die Geschichte zieht sich wie ein Strudelteig; wenn sie Hagen erschlagen will, warum tut sie's nicht gleich?

Die ganze Zeit spricht sie davon, Siegfried rächen zu wollen; in der allerletzten Szene, wo sie den Hagen erschlägt, fängt sie plötzlich vom Nibelungenschatz an, von dem bisher nur ganz nebenbei die Rede war. Also nur um das Gold ist ihr zu thun gewesen?

Zum Schluss übernimmt Dietrich von Bern die Herrschaft "im Namen dessen, der am Kreuz erblich." Also wieder ein neues Thema, von dem man vordem höchstens Andeutungen gehört hat. Ohne Sinn und Verstand!

Dass Brünhilde, nachdem sie so bedeutungsvoll eingeführt worden ist, einfach untern Tisch fällt, davon ganz abgesehen. (Auch darin ist Wagner logischer.)

Diese Fehler werden jedenfalls von Vorzügen überwogen, die mir nicht erkennbar sind. Aber da sind sie, die Fehler.

Ludwig to Paul. 26.1.1935

Many thanks for your long letter. I can only answer in a fragmentary and quite unsatisfactory manner. The more so since I haven't the Hebbel by me and haven't read it for a long time.

I believe none of the features you criticize is really a mistake but in saying that I am in no doubt that one can say that the powers of the writer were not remotely adequate to represent the conflicts that call for representation here. What this comes to is that in the last resort the attempt was not a successful one. It's rather, I think, as if one were reading a book about for example aesthetics, which one found to be as a whole, as a systematic treatment, mistaken and yet to contain again and again scattered remarks of great value on the theme. In this case too one continually notes profound observations and brilliant aperçus, many more no doubt than I can even imagine. I think one can as little compare Hebbel and Wagner as one could a blind man with a lame one, except in so far as neither can walk properly. In Wagner there isn't the least trace of tragedy from beginning to end, any more than there is in a myth or a fairy tale. I.e. there are no clashes between powers that we feel to be equally justified. If there are clashes then it is between light and darkness. For Hebbel 
the essential thing is that both sides are in the right. Thus in Wagner there are no problems, whereas Hebbel abounds in problems. And in his case the clashes are always between types, cultures, peoples, races, periods - see [his] Herodes und Mariamne, Gyges, Genoveva. One could even say that the second half of the $19^{\text {th }}$ Century was constantly concerned with the problem of race, i.e. with the comparison, the evaluation, and the claims of different races. Hence we also find among Hebbel's works of that period Die Jüdin, Die Argonauten, and Die Makkabäer. In all of these a confrontation occurs (whereas in [Lessing's] Nathan there is no confrontation in this sense.

For Wagner, on the other hand, the problem is solved and light is marked off from darkness. (Which is why the other [dramas] are in better taste [nearer to decency].)

Wagner's is an attempt to dramatize a myth whereas Hebbel wants to show the clash between different worlds including the clash between a world full of mystery and the world of everyday. So much for your first ground of complaint.

As for the second [it is not perfectly clear how Ludwig divides Paul's letter], this is not a mistake at all (or so I believe). Is the character of the King in Die Jüdin heroic or base? Both!

Only that can properly be called a mistake whose removal or correction would improve the mistaken whole.

Kriemhild takes her revenge not simply on two people but on a whole culture. (Just like when Daisy Nagy wouldn't let her children learn German.) She allies herself to a foreign culture against the house of her own family. The difference between the two cultures is displayed splendidly in the dialogue between Etzel and Dietrich before the arrival of the Nibelungen.

That a new theme is introduced as epilogue is not in itself a mistake, but I would not say that it here has the effect that it ought to have produced. The meaning however is that at the end the whole old epoch with all its conflicts goes under and a new one arises. But enough and more than enough! [Ludwig here adopts the preaching tone his father loved to mock.]

Herzlichen Dank für Deinen langen Brief. Ich werde Dir ihn nur abgerissen \& ganz ungenügend beantworten können. Umsomehr als ich den Hebbel nicht bei mir habe $\&$ ihn schon lange nicht mehr gelesen habe.

Ich glaube, keiner der Züge die Du tadelst ist wirklich ein Fehler; \& dabei bin ich doch nicht im Zweifel, daß man sagen kann, die Kraft des Dichters habe nicht entfernt zur Darstellung der Konflikte ausgereicht, die hier dargestellt werden sollen. Womit ich aber nur sagen will, daß letzten Endes das Unternehmen nicht gelungen ist. - Es ist, glaube ich, als lese man ein Buch, sagen wir über Aesthetik, \& fände es im ganzen, als System, verfehlt, aber immer wieder ausgezeichnete Bemerkungen $\mathrm{zu}$ dem Thema durch das Buch verstreut. 
So kann man auch hier immer wieder tiefe Blicke \& schöne Erfindungen sehen, \& gewiß viel mehr solche als ich es immer nur ahnen kann. Ich glaube, vergleichen kann man Hebbel \& Wagner so wenig wie einen Blinden \& einen Lahmen, außer insofern, als - beide nicht recht gehen können. In Wagner ist nicht das geringste Tragische von Anfang bis zum Ende; sowenig wie in einem Märchen oder im Mythos. D. h. es sind nirgends Zusammenstöße von Mächten, die wir als gleichberechtigt empfinden. Wo Zusammenstöße sind, da zwischen Licht \& Finsternis. Das Wesentliche für Hebel ist gerade, daß jeder Recht hat. D. h.: bei Wagner ist kein Problem, während es bei Hebel von Problemen wimmelt. Und zwar sind die Zusammenstöße bei ihm immer zwischen Typen: Kulturen, Völkern, Rassen, Zeitaltern (Vergl. ,Herodes \& Mariamne', ,Gyges', ,Genoveva'). - Man könnte auch so sagen: Die zweite Hälfte des $19^{\text {ten }}$ Jahrhunderts hat sich immer wieder mit dem Rassenproblem beschäftigt; d. h., mit dem Vergleich, der Wertung, den Ansprüchen der Rassen. Daher damals unter den Hebbelschen Dramen, auch die ,Jüdin', die ,Argonauten', die ,Makabäer' entstanden sind. In allen diesen findet eine Auseinandersetzung statt. (Im Natan ist dagegen in diesem Sinne keine Auseinandersetzung.) Für Wagner ist dagegen das Problem gelöst \& Licht \& Finsternis geschieden. (Darum schon sind die Andern so viel anständiger.)

Bei Wagner soll der Mythos dramatisiert werden; bei Hebbel soll der Zusammenstoß zwischen verschiedenen Welten gezeigt werden und zwar unter anderem der Zusammenstoß sozusagen einer geheimnisvollen \& einer alltäglichen. Das bezieht sich auf Deinem ersten Tadel.

Ad No.2: dies ist, glaube ich durchaus kein Fehler. Ist der Charakter des Königs in der ,Jüdin' heldenhaft oder niedrig? Beides! -

Fehler kann man eigentlich nur das nennen, dessen Beseitigung oder Korrektur die fehlerhafte Sache verbessern würde.

Kriemhild rächt sich nicht einfach an zwei Leuten, sondern an einer ganzen Kultur. (Das ist, wie wenn die Dasy Nagy ihre Kinder nicht deutsch lernen läßt.) Sie verbündet sich mit einer fremden Kultur gegen die ihres Elternhauses. Der Unterschied der beiden Kulturen wird in großartiger Weise auseinandergesetzt im Gespräch zwischen Etzel \& Dietrich vor der Ankunft der Nibelungen.

Der Hort \& Siegfried sind für Kriemhild in gewissem Sinne Eins. Den Hort

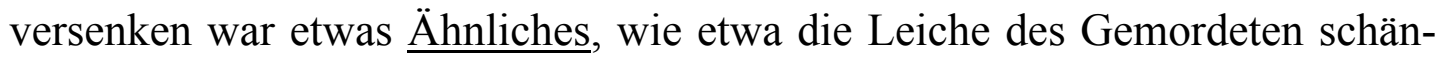
den - das empfindet man auch nicht darum als schmerzhaft, weil einem am toten Körper soviel gelegen ist. Siegfried war für Kriemhild Macht \& Stärke \& der Hort ist ein Symbol dieser Macht in mehr als einem Sinn.

Daß, sozusagen als Epilog, ein neues Thema eingeführt wird, ist glaube ich, allein kein Fehler; aber ich will nicht sagen, daß es hier die Wirkung tut, die es tun sollte. Der Sinn ist doch der, daß am Ende die ganze alte Epoche mitsamt 
ihren Konflikten versinkt \& eine neue anbricht. Aber nun genuch \& übergenuch!!

Ludwig to Paul. Letter from the 1920s.

I think you are unwilling to lose yourself in and behind the composition: on the contrary, it's yourself that you want to present. I am well aware that, that way too, something comes out that's worth hearing, and I don't mean just for a hearer who admires the technique, but also for me and for anyone who can appreciate the expression of a personality. On the other hand I wouldn't turn to you if I wanted (as I usually do) to hear a composer speak.

But even here there are a couple of exceptions, I mean, for example Wagner. (I won't now start to philosophize about why you bring a different sense to your interpretation of Wagner from that of most other composers.) And also Labor, whom you play with a certain self-renunciation (or so it seems to me)

Du willst Dich - glaube ich - nicht hingeben \& hinter der Komposition zurücktreten, sondern Du willst Dich selbst darstellen. Ich weiß nun, daß auch dabei etwas heraus kommt, das dafürsteht gehört zu werden \& zwar meine ich nicht nur für den, der die Technik bewundert, sondern auch für mich \& jeden der einen Ausdruck einer Persönlichkeit zu schätzen weiß. Dagegen werde ich mich nicht an Dich wenden, wenn ich (wie es bei mir meistens der Fall ist) einen Komponisten sprechen hören möchte. Aber auch hier gibt es ein paar Ausnahmen und zwar z.B. Wagner. (Ich werde jetzt nicht anfangen, darüber zu philosophieren, warum Du Wagner in einem anderen Sinne wiedergibst, als die meisten anderen Komponisten) \& auch Labor, den Du mit einer gewissen Selbstentäußerung spielst (oder mir zu spielen scheinst). 
